\title{
Environmental Risk Assessment and Management in Oil Platform Construction Phase Activities: A Case Study
}

\author{
Azad Younesi \\ Novo Nordisk \\ Company \\ Iran
}

\author{
Raouf Rahmani \\ Urban Water and Waste \\ Water Company \\ Baneh, Iran
}

\author{
Jalil Jaafari \\ Dpt of Environmental Health \\ Engineering, School Of Public \\ Health, Tehran University Of \\ Medical Sciences, Tehran, Iran
}

\author{
Yousef Mahdavi \\ Dpt of Environmental Health \\ Engineering, Health Sciences Research \\ Center, Mazandaran University Of \\ Medical Sciences, Iran
}

\begin{abstract}
The construction phase is one of the very risky stages engaged in oilfields, which usually involves minor to severe human, financial, and environmental damages. It includes a major part of lost working times, and in recent years, along with the development of oilfields and oil platform construction activities in Iran, hazardous risks and events have occurred and have been recorded. Therefore, this study aims to reduce the negative effects of the risks engaged in oil platform construction activities in the region under study, i.e. the Abuzar oilfield. The indexing system method, along with determining the importance index, effect, and frequency of occurrence, was used in this study to evaluate the environmental risks of oil platform construction activities in Abuzar oilfield. First, the project activities were identified and then, the effect of desired activities on environmental aspects (water, air, soil, human, waste production, and noise) was investigated. For quantitative estimation of risk values through interviewing the experts and using the tables of intensity, effect, and frequency of event occurrence, were calculated based on the formula governing the effect of different activities on the environment, and the risk value was determined. The research findings indicated that most of the environmental risks are in the range of average risks $(\mathbf{7 2 . 9} \%)$ however $\mathbf{2 0 . 2 \%}$ are in the range of low risks and $6.9 \%$ are in the range of high risks. Finally, considering experts' viewpoints, management solutions were proposed to reduce the risk of activities, and the risk priority numbers were calculated after performing the corrective actions.
\end{abstract}

Keywords-risk assessment and management; Abuzar oilfield; oil; platform; environment

\section{INTRODUCTION}

Any engineering project encounters several risks during its life cycle. Thus, in case of confronting any danger or risk, its consequences must be evaluated [1]. Risk management refers to the systematic process of identifying, analyzing, and reacting to the risks involved in a project [2]. This management guarantees maximizing the probability and consequences of positive events, and minimizing the probability and consequences of negative events regarding the project objectives [3]. Risk management acts as a prediction tool. It probes the uncertain future to identify the things that might cause serious risks and prevents them, or seeks for an important opportunity $[4,5]$. Oilfield exploration and production from oil reservoirs is one of the projects always associated with high risks $[6,7]$. Due to their unique features, the plans and projects related to oil industry are totally different to other plans and projects in terms of extent and type of the risk [8,9]. The features and characteristics distinguishing oil industry plans and projects from other plans is the great volume of investment and long-term plans in this industry [9], so that the longer the plan implementation, the higher the associated uncertainties and risks $[10,11]$. Another unique feature in implementing the oilfield development plans is unknown and uncertain oil volume to be produced as the oil reservoir is located hundreds of meters under the ground, and it is not possible to certainly determine its volume, quality, and distribution $[12,13]$.

The construction phase is one of the very risky stages engaged in oilfields, which usually involves minor to severe human, financial, and environmental damages, and includes a major part of lost working times $[14,15]$, so that in recent years, along with the development of oilfields and oil platform construction activities in Iran, hazardous risks and events have occurred and recorded [16-18] and several studies have addresses environmental risk management and evaluation in construction phases of oil projects in general and oilfields in particular $[9,19,20]$. This study aims to reduce the negative effects of the risks engaged in oil platform construction activities in the region under study, i.e., Abuzar oilfield. Abuzar oilfield, located $75 \mathrm{~km}$ from western Khark Island, includes three major production platforms of $\mathrm{AA}, \mathrm{AB}$, and $\mathrm{AC}$. It has the greatest share of oil production in the Persian Gulf and Iran. Each oil platform in this field has the capacity of producing 80,000 barrels of oil per day. Totally, 195,000220,000 barrels of oil is produced from this field on a daily basis. So far, 107 oil wells have been drilled in Abuzar oilfield. According to the estimations, total reserve of this field is about 
4 billion barrels of oil, $20 \%$ of which can be produced. The current production capacity of Abuzar oilfield is 240,000 barrels per day. Given the great oil volume of this field and the importance of oil platform construction risks due to the risky operations involved, risk assessment in Abuzar oilfield is necessary. Efforts have been made in this study to thoroughly investigate and identify the activities performed in the site and determine their potential damages in order to take the necessary measures for environmental risk management and reducing the risks prevailing in the site.

\section{METHOD}

The environmental risk assessment method used in this study has a general application in a wide range of risks [21].
According to this model, the primary focus is on identifying the plan activities. The plan activities were completely identified based on the field visits from Abuzar oilfield platform construction plan. Then, the effect of the desired activities on environmental aspects (water, air, soil, human, waste production, and noise) were investigated. In order to specify and classify the unexpected activities and events leasing to environmental risks in the projects, the unexpected activities and events in Abuzar oilfield platform construction and their effects on environmental aspects were identified by investigating valid and scientific documents and expert survey, reported in Table I.

TABLE I. UNEXPECTED ACTIVITIES AND EVENTS IN THE OPERATIONAL SITE OF CONSTRUCTING ABUZAR OILFIELD PLATFORMS AND THEIR EFFECTS ON ENVIRONMENTAL ASPECTS

\begin{tabular}{|c|c|c|c|c|c|c|c|}
\hline No. & Activities & $\begin{array}{c}\text { Water } \\
\text { pollution }\end{array}$ & $\begin{array}{c}\text { Air } \\
\text { pollution }\end{array}$ & $\begin{array}{c}\text { Soil } \\
\text { pollution }\end{array}$ & Noise & Waste & $\begin{array}{l}\text { Effect on human } \\
\text { health }\end{array}$ \\
\hline 1 & Pipe and equipment transportation & - & $*$ & $*$ & * & - & $*$ \\
\hline 2 & Pipe and equipment lifting and displacing & - & $*$ & $*$ & * & - & $*$ \\
\hline 3 & $\begin{array}{l}\text { Gouging (preparing the welding point to complete the } \\
\text { welding process) }\end{array}$ & - & $*$ & $*$ & $*$ & $*$ & $*$ \\
\hline 4 & Pulverizing and using stone grinding device & - & $*$ & * & $*$ & $*$ & $*$ \\
\hline 5 & Pipe insulation & - & $*$ & $*$ & - & * & $*$ \\
\hline 6 & Acetylene production and distribution & $*$ & $*$ & * & - & * & $*$ \\
\hline 7 & Hydrostatic pressure test & - & $*$ & $*$ & $*$ & - & $*$ \\
\hline 8 & Scaffolding & - & - & - & - & $*$ & $*$ \\
\hline 9 & Construction and repair of access roads & $*$ & $*$ & * & * & * & $*$ \\
\hline 10 & Digging foundation, piling, flooring, and soil compression & $*$ & $*$ & $*$ & $*$ & $*$ & $*$ \\
\hline 11 & Storing the equipment, pipes, goods, and chemicals & - & $*$ & $*$ & * & * & $*$ \\
\hline 12 & Painting & - & * & - & * & * & $*$ \\
\hline 13 & Tension removal & - & $*$ & - & - & $*$ & $*$ \\
\hline 14 & Sand blast & - & $*$ & * & * & $*$ & $*$ \\
\hline 15 & $\begin{array}{l}\text { Secondary events, including fire and explosion caused by the } \\
\text { adjacent projects }\end{array}$ & $*$ & $*$ & $*$ & $*$ & $*$ & $*$ \\
\hline 16 & Maritime transportation and unloading & $*$ & $*$ & - & * & * & $*$ \\
\hline 17 & Gasoline reservoir test & - & * & - & * & - & * \\
\hline 18 & Running electricity networks & - & - & - & - & $*$ & $*$ \\
\hline 19 & Solid waste production & $*$ & $*$ & $*$ & - & - & - \\
\hline 20 & Wastewater production & $*$ & $*$ & $*$ & - & - & - \\
\hline 21 & Emergency evacuation under emergency situations & $*$ & - & $*$ & * & - & $*$ \\
\hline 22 & Industrial radiography & $*$ & $*$ & $*$ & - & * & $*$ \\
\hline 23 & Non-destructive tests & - & $*$ & $*$ & - & $*$ & $*$ \\
\hline 24 & Welding, electrode cutting, and electrode warming & - & * & $*$ & * & * & * \\
\hline 25 & Manual air and gas cutting, assembling & - & $*$ & $*$ & $*$ & $*$ & $*$ \\
\hline 26 & Working in closed environment & - & $*$ & $*$ & * & $*$ & $*$ \\
\hline 27 & De-rusting operations & - & $*$ & $*$ & $*$ & $*$ & $*$ \\
\hline 28 & Carpentry and wood cutting & - & $*$ & $*$ & $*$ & $*$ & $*$ \\
\hline 29 & Green space and gardening & $*$ & - & $*$ & $*$ & $*$ & $*$ \\
\hline 30 & Fiberglass pulp cutting & - & $*$ & $*$ & * & $*$ & $*$ \\
\hline 31 & Repairing the machinery & - & $*$ & $*$ & - & - & - \\
\hline 32 & Cooking & $*$ & $*$ & - & $*$ & $*$ & $*$ \\
\hline 33 & Fire fighting & $*$ & $*$ & $*$ & - & * & $*$ \\
\hline 34 & Waste incineration & - & * & * & * & * & $*$ \\
\hline 35 & Waste production and industrial waste storage & - & $*$ & $*$ & $*$ & - & $*$ \\
\hline 36 & Using heavy and light vehicles in the site and road & - & $*$ & $*$ & $*$ & - & $*$ \\
\hline 37 & Tour living, working in onshore and operational site & - & $*$ & * & - & $*$ & $*$ \\
\hline 38 & Health care & - & - & - & - & $*$ & $*$ \\
\hline 39 & Manual transportation & - & - & - & - & $*$ & - \\
\hline 40 & Site visitors & - & - & - & - & - & $*$ \\
\hline 41 & MT and PT destructive tests & - & * & - & - & $*$ & $*$ \\
\hline 42 & War, earthquake, and Tsunami & $*$ & $*$ & $*$ & $*$ & $*$ & $*$ \\
\hline 43 & Ultrasonic tests and phase array & - & $*$ & - & - & $*$ & $*$ \\
\hline
\end{tabular}


Quantitative estimation of risk values was performed through interviewing the experts, including the professionals in the fields of environment and HSE, who have a comprehensive knowledge about the site under study, and using the tables of intensity, effect, and frequency of event occurrence. Environmental risk values were calculated based on the following formula [23] governing the effect of different activities on the environment:

Environmental risk $=$ the effect of activity on environmental aspects $\times$ the importance of activity in environmental aspects $\times$ the frequency of event occurrence.

and the risk value was quantitatively determined, and recorded in the RPN column of a prepared datasheet before performing the corrective actions [22]. After determining the activities and identifying the effects of air, soil, and water pollution, noise, waste, and the damage caused by these activities in order to quantify the risk associated with them, Table II of importance, effect, and frequency of event occurrence was created.

The risk level based on importance, effect, and frequency of event occurrence is as the following [24, 25] (Table III):
A. Low risk: 1-14
B. Moderate risk: 15-79
C. High risk: $80-125$

TABLE II. RISK CLASSIFICATION MATRIX BASED ON IMPORTANCE, EFFECT, AND FREQUENCY OF EVENT OCCURRENCE

\begin{tabular}{|c|c|c|c|c|c|c|}
\hline $\begin{array}{c}\text { importance } \\
\text { effect }\end{array}$ & $\mathbf{1}$ & $\mathbf{2}$ & $\mathbf{3}$ & $\mathbf{4}$ & $\mathbf{5}$ & frequency \\
\hline 1 & 1 & 2 & 3 & 4 & 5 & 1 \\
\hline 2 & 4 & 8 & 12 & 16 & 29 & 2 \\
\hline 3 & 9 & 19 & 27 & 36 & 45 & 3 \\
\hline 4 & 16 & 32 & 48 & 64 & 80 & 4 \\
\hline 5 & 35 & 50 & 75 & 100 & 125 & 5 \\
\hline
\end{tabular}

After determining the type of risk, a complete list of actions to control and reduce the risk values were developed and discussed in an expert meeting. The best actions were selected by the experts and its list was confirmed by the risk assessment team, so that it could be announced to the project manager in order to reduce environmental risks. Finally, the risk value was determined quantitatively after performing the corrective actions.

\section{RESEARCH FINDINGS}

The environmental risk values determined based on the results of field visits and related expert meetings for Abuzar oilfield platforms are given in Table IV. An example of calculating the environmental risks caused by project activities before/after performing the corrective actions is shown in this table. Following, the analysis results of Abuzar oilfield platform are explained. Furthermore, according to Table V, quantitative risk assessment during construction showed that $20.2 \%$ of risks had the numerical values in the range of 1-14 (low), $72.9 \%$ of the risks had numerical values in the range of
15-79 (moderate risk), and $6.9 \%$ of the risks had numerical values greater than 80 (Figure 1). According to the management strategies proposed in this stage to remove, reduce, and control environmental risk, a re-evaluation was performed on the project risk values after performing corrective actions, and the number of project risks decreased according to Table VI after performing corrective actions. According to Table VI, quantitative evaluation of environmental risks involved in the project during construction after performing corrective actions showed that $80.3 \%$ environmental risks involved in construction phase are low risks, $19.7 \%$ of the risks are moderate risks (15-79), and $100 \%$ of the high risks were removed after performing corrective actions (Figure 2).

TABLE III. IMPORTANCE, EFFECT, AND FREQUENCY OF EVENT OCCURRENCE ON ENVIRONMENTAL ASPECTS

\begin{tabular}{|c|c|c|c|}
\hline $\begin{array}{c}\text { Numerical } \\
\text { Index }\end{array}$ & Importance & Effect & Frequency \\
\hline 1 & $\begin{array}{c}\text { An insignificant amount } \\
\text { (if any) is distributed in } \\
\text { the environment }\end{array}$ & $\begin{array}{c}\text { Its effect is } \\
\text { beyond the } \\
\text { control of the } \\
\text { unit }\end{array}$ & $\begin{array}{c}\text { Never or less } \\
\text { than once a } \\
\text { year }\end{array}$ \\
\hline 2 & $\begin{array}{c}\text { A little amount is } \\
\text { distributed in the } \\
\text { environment }\end{array}$ & $\begin{array}{c}\text { Has a little } \\
\text { effect }\end{array}$ & $\begin{array}{c}\text { Once in a 1-3 } \\
\text { years }\end{array}$ \\
\hline 3 & $\begin{array}{c}\text { An average amount is } \\
\text { distributed in the } \\
\text { environment }\end{array}$ & $\begin{array}{c}\text { Has an } \\
\text { average effect }\end{array}$ & $\begin{array}{c}\text { Once a month } \\
\text { to once a year }\end{array}$ \\
\hline 5 & $\begin{array}{c}\text { A great amount is } \\
\text { distributed in the } \\
\text { environment }\end{array}$ & $\begin{array}{c}\text { Has a great } \\
\text { effect }\end{array}$ & $\begin{array}{c}\text { Once a week } \\
\text { to once a } \\
\text { month }\end{array}$ \\
\hline 5 & $\begin{array}{c}\text { Distribution completely } \\
\text { depends on the } \\
\text { environment }\end{array}$ & $\begin{array}{c}\text { Has a direct } \\
\text { effect }\end{array}$ & $\begin{array}{c}\text { Once a day to } \\
\text { once a week }\end{array}$ \\
\hline
\end{tabular}

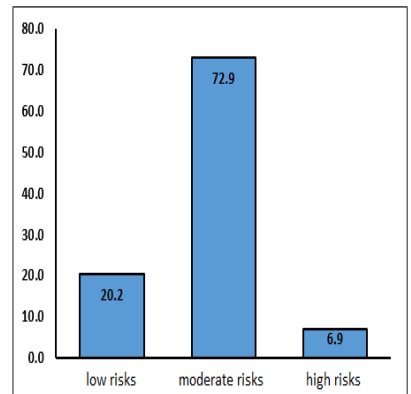

Fig. 1. Percentage of different environmental risks in the project before performing corrective actions

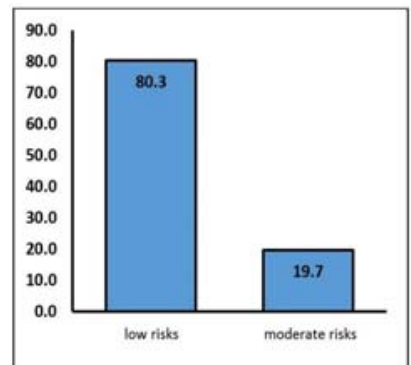

Fig. 2. Percentage of different environmental risks involved in the project after performing corrective actions 
TABLE IV. ENVIRONMENTAL RISKS CAUSED BY PROJECT ACTIVITIES BEFORE/AFTER PERFORMING CORRECTIVE ACTIONS

\begin{tabular}{|c|c|c|c|c|}
\hline No. & Activity & $\begin{array}{c}\text { Risk estimation before } \\
\text { performing the corrective } \\
\text { actions }\end{array}$ & $\begin{array}{l}\text { Risk estimation after } \\
\text { performing the corrective } \\
\text { actions }\end{array}$ & $\begin{array}{c}\text { Decrease in risk } \\
\text { value }(\%)\end{array}$ \\
\hline 1 & Pipe and equipment transportation & 112 & 46 & 58.9 \\
\hline 2 & Pipe and equipment lifting and displacing & 112 & 46 & 58.9 \\
\hline 3 & Using heavy and light vehicles in the site and road & 105 & 42 & 60.0 \\
\hline 4 & Gouging & 74 & 32 & 56.8 \\
\hline 5 & Pulverizing and using stone grinding device & 140 & 85 & 39.3 \\
\hline 6 & Pipe insulation & 95 & 35 & 63.2 \\
\hline 7 & Acetylene production and distribution & 160 & 80 & 50.0 \\
\hline 8 & Pressure test & 78 & 38 & 51.3 \\
\hline 9 & Scaffolding & 56 & 25 & 55.4 \\
\hline 10 & Construction and repair of access roads & 74 & 24 & 67.6 \\
\hline 11 & Digging foundation, piling, flooring, and soil compression & 112 & 68 & 39.3 \\
\hline 12 & Storing the equipment, pipes, goods, and chemicals & 160 & 64 & 60.0 \\
\hline 13 & Painting & 76 & 20 & 73.7 \\
\hline 14 & Tension removal & 145 & 60 & 58.6 \\
\hline 15 & Sand blast & 245 & 120 & 51.0 \\
\hline 16 & $\begin{array}{l}\text { Secondary events, including fire and explosion caused by the } \\
\text { adjacent projects }\end{array}$ & 188 & 160 & 14.9 \\
\hline 17 & War, earthquake, and Tsunami & 242 & 204 & 15.7 \\
\hline 18 & Maritime transportation and unloading & 74 & 40 & 45.9 \\
\hline 19 & Gasoline reservoir test & 70 & 32 & 54.3 \\
\hline 20 & Running electricity networks & 20 & 10 & 50.0 \\
\hline 21 & Solid waste production & 314 & 70 & 77.7 \\
\hline 22 & Wastewater production & 380 & 120 & 68.4 \\
\hline 23 & Emergency evacuation & 44 & 25 & 43.2 \\
\hline 24 & Industrial radiography & 314 & 112 & 64.3 \\
\hline 25 & $\begin{array}{l}\text { Working with cutting device, including CNC (Muller) and hand- } \\
\text { held torches }\end{array}$ & 124 & 44 & 64.5 \\
\hline 26 & $\begin{array}{l}\text { Gas welding and electrode cutting in open and closed } \\
\text { environment }\end{array}$ & 160 & 52 & 67.5 \\
\hline 27 & Manual air and gas cutting, assembling & 110 & 38 & 65.5 \\
\hline 28 & Working in closed environment & 276 & 124 & 55.1 \\
\hline 29 & De-rusting operations & 78 & 32 & 59.0 \\
\hline 30 & Carpentry and wood cutting & 124 & 56 & 54.8 \\
\hline 31 & Green space and gardening & 98 & 44 & 55.1 \\
\hline 32 & Fiberglass pulp cutting & 120 & 52 & 56.7 \\
\hline 33 & Repairing the machinery & 262 & 84 & 67.9 \\
\hline 34 & Cooking & 244 & 82 & 66.4 \\
\hline 35 & Fire fighting & 110 & 56 & 49.1 \\
\hline 36 & Waste incineration & 136 & 64 & 52.9 \\
\hline 37 & Waste production and industrial waste storage & 202 & 88 & 56.4 \\
\hline 38 & Working in onshore and working in site & 286 & 72 & 74.8 \\
\hline 39 & Health care & 74 & 12 & 83.8 \\
\hline 40 & Manual transportation & 108 & 32 & 70.4 \\
\hline 41 & Site visitors & 36 & 12 & 66.7 \\
\hline 42 & MT and PT destructive tests & 70 & 10 & 85.7 \\
\hline 43 & Ultrasonic tests and phase array & 64 & 22 & 65.5 \\
\hline
\end{tabular}

TABLE V. TYPE AND VALUE OF THE ENVIRONMENTAL RISKS DURING CONSTRUCTION

\begin{tabular}{|c|c|}
\hline Risk classification & $\begin{array}{c}\text { The number of environmental risks in } \\
\text { construction phase }\end{array}$ \\
\hline Low risks (1-14) & 38 \\
\hline Moderate risks (15-79) & 137 \\
\hline High risks (80-125) & 13 \\
\hline total & 188 \\
\hline
\end{tabular}

According to Table VII, the number of low environmental risks during construction phase after performing corrective actions increased from 38 to 151 , which indicates $74.84 \%$ increase in low risks after performing corrective actions.
Moreover, the number of moderate environmental risks during construction phase after performing corrective actions decreased from 137 to 37 , which indicates $72.98 \%$ decrease in moderate risks involved in construction phase. The number of environmental risks with values greater than 80 also reached zero, which indicates $100 \%$ decrease in high environmental risks after performing corrective actions.

\section{DISCUSSION AND CONCLUSION}

Among all oil companies and installations, the oil platforms and production facilities, especially compared to onshore and offshore facilities, are of great importance in terms of 
environmental damages due to their distance from the beach, great number of personnel, significant reserves of hydrocarbon and chemicals, unique operational conditions, and the potential to cause huge industrial accidents. Therefore, knowing about their environmental aspects and consequences has an important and valuable role. Final results in this study indicated that the construction phase is one of the very risky stages engaged in oilfields, which usually involves minor to severe environmental damages. Most of the environmental damages are in the range of moderate risks $(72.9 \%), 20.2 \%$ are in the range of low risks, and $6.9 \%$ are in the range of high risks.

TABLE VI. QUANTITATIVE EVALUATION OF ENVIRONMENTAL RISKS INVOLVED IN THE PROJECT DURING CONSTRUCTION AFTER PERFORMING CORRECTIVE ACTIONS

\begin{tabular}{|c|c|}
\hline Risk classification & $\begin{array}{c}\text { The number of environmental risks involved } \\
\text { in construction phase }\end{array}$ \\
\hline Low risks (1-14) & 151 \\
\hline Moderate risks (15-79) & 37 \\
\hline High risks (80-125) & - \\
\hline Total & 188 \\
\hline
\end{tabular}

TABLE VII. ESTIMATING THE VALUES OF RISKS INVOVLVED IN THE PROJECT DURING CONSTRUCTION PHASE AFTER PERFORMING CORRECTIVE ACTIONS

\begin{tabular}{|c|c|}
\hline Risk classification & $\begin{array}{c}\text { The number of environmental } \\
\text { risks involved in construction } \\
\text { phase }\end{array}$ \\
\hline $\begin{array}{c}\text { Percentage of increase in low risks } \\
\text { after performing corrective actions (1- } \\
14)\end{array}$ & $74.84 \%$ \\
\hline $\begin{array}{c}\text { Percentage of decrease in moderate } \\
\text { risks after performing corrective } \\
\text { actions (15-79) }\end{array}$ & $72.97 \%$ \\
\hline $\begin{array}{c}\text { Percentage of decrease in high risks } \\
\text { after performing corrective actions } \\
(>80)\end{array}$ & $100 \%$ \\
\hline
\end{tabular}

The results of [26] on classification of different risks prevailing in the development of oil and gas fields showed that the exploration stage is considered as the riskiest stage in development of an oilfield. Another previous research to evaluate the environmental risk using EFMEA method indicated that the greatest environmental risk is attributed to the construction phase, and $20 \%$ of its risk are in the range of low risks, $62 \%$ are in the range of medium risk and $18 \%$ are in the range of high risk [18]. In [27], authors addressed the evaluation and selection of risk responses of the projects during construction phase. Their results showed that risk evaluation results in a significant improvement in time, cost, and quality of the project during construction phase. In a similar research [28], authors studied environmental risk management and evaluation in Abadan. The purpose of their study was to remove, reduce, and control the existing environmental risks. 57 risk factors were determined during construction phase. Except the 21 environmental risks that were within an acceptable range, all of them were in the range of high risks, and suitable control measures in accordance with the activity or the process had to be taken. In [29], authors investigated the factors associated with event occurrence in the construction phase of oil, gas, and petrochemical projects in Assaluyeh and identifies four variables contributing in fatal occupational accidents during construction phase of the projects: unsafe conditions, unsafe operations, mismanagement factors, and using defective tools, materials, equipment and machinery, among which the unsafe conditions and mismanagement factors have a greater effect on occurrence of fatal accidents during construction phase.

\section{Suggestions}

The following corrective actions are suggested to reduce the environmental risks identified and minimize them:

1) Completing the environmental procedures and guidelines available in form of an integrated management system.

2) Holding educational and training courses required for all employees at different levels to increase their level of knowledge and awareness regarding environmental issues. Some of the important environmental educational courses identified during studies, which are necessary to be held for the employees are:

- Professional courses on risk assessment and evaluation for the experts in upper and middle levels

- Professional courses on combating oil pollution

- Managing emergency situation

- Managing the wastes at different levels

3) Holding monthly meetings of HSE committee, with presence of the authorities, HSE experts, and contracting representatives in order to investigate the problems and propose a schedule to solve the problems and challenges.

4) Integrating the preventive maintenance system in all operational sites under computerized maintenance management system.

5) Performing environmental monitoring continuously and according to the integrated management system requirements and self-reported plan of environmental protection agencies.

6) Removing the inconsistencies identified in the internal and external audits of the company and performing the corresponding corrective actions.

7) Adopting preventive policies to control environmental risks, rather than the current reactive policies and procedures.

8) Environmental risk assessment and analyzing the consequences before installing the new equipment or any changes in the process.

9) Updating meteorological information (e.g., temperature, humidity, wind direction, wave height, predicting the storm and unfavorable weather conditions). 
10) Identifying certain regions and neighboring organizations and companies for mutual cooperation in emergency cases.

11) Supplying the equipment required to prevent oil pollution, namely booms, skimmers, and oil separator elements (OSE), in case of oil leakage and spilling into the sea.

12) Using suitable inhibitors against internal and external corrosion of the equipment and pipes, and implementing corrosion management actions in offshore oil facilities.

13) Conducting periodic and regular inspections of the facilities regarding HSE, technical inspection, corrosion engineering, and thickness measurement.

14) Performing periodic and regular maneuvers with different scenarios in Abuzar oilfield platform.

15) Necessity of meeting environmental principles by the contracting companies working on the platform.

16) Informing the employees of contracting companies about the environmental aspects and consequences involved in the working environment.

17) Necessitating the contracting companies to identify and evaluate environmental risks associated with the activities performed in the platform.

\section{REFERENCES}

[1] K. Smith, Environmental hazards: assessing risk and reducing disaster. Routledge, 2013

[2] L. I. V. Bergh, S. Hinna, S. Leka, A. Jain, "Developing a performance indicator for psychosocial risk in the oil and gas industry", Safety Science, Vol. 62, No. 2, pp. 98-106, 2014

[3] S. A. Mirjalili, Fundamentals and principles of risk assessment and management in the environment, Andishmandan-e-Yazd Publications, 2009

[4] M. Jabari-Gharebagh, Risk assessment and evaluation in the transportation pipelines of oil, gas, and petrochemical products, Tehran University, Tehran, 2008

[5] A. Ambituuni, J. Amezaga, E. Emeseh, "Analysis of safety and environmental regulations for downstream petroleum industry operations in Nigeria: Problems and prospects", Environmental Development, Vol. 9, No. 4, pp. 43-60, 2014

[6] H. Hosseini, T. Dana, R. Arjmandi, I. Shirianpour, Safety risk management and occupational health in the construction phase of oil platforms and presenting management strategies for improvement (case study: construction phase of Reshadat oilfield), Tehran Publication, 2012

[7] I. Christel, G. Certain, A. Cama, D. R. Vieites, X. Ferrer, "Seabird aggregative patterns: A new tool for offshore wind energy risk assessment", Marine Pollution Bulletin, Vol. 66, No. 1, pp. 84-91, 2013

[8] R. A. Ronconi, K. A. Allard, P. D. Taylor, "Bird interactions with offshore oil and gas platforms: review of impacts and monitoring techniques", Journal of Environmental Management, Vol. 147, No. 2, pp. 34-45, 2015

[9] J. E. Skogdalen, J. E. Vinnem, "Quantitative risk analysis of oil and gas drilling, using Deep-water Horizon as case study", Reliability Engineering \& System Safety, Vol. 100, No. 2, pp. 58-66, 2012

[10] F. Miraj, M. S. Fatemi, M. Valinezhad, Proposing an applied model for risk assessment in oil and gas pipelines, Sharif University of Technology, Tehran, 2009
[11] W. Xingfeng, "Review on Comprehensive Evaluation \& Optimization of Petroleum Engineering Program [J]", Petroleum Planning \& Engineering, Vol. 6, No. 3, pp. 1-4, 2009

[12] D. M. Canu, C. Solidoro, V. Bandelj, G. Quattrocchi, R. Sorgente, A. Olita, A. Cucco, " Assessment of oil slick hazard and risk at vulnerable coastal sites", Marine Pollution Bulletin, Vol. 94, No. 1, pp. 84-95, 2015

[13] A. H. Hu, C. W. Hsu, T. C. Kuo, W. C. Wu, "Risk evaluation of green components to hazardous substance using FMEA and FAHP", Expert Systems with Applications, Vol. 36, No. 3, pp. 7142-7147, 2009

[14] B. Razavi-Dezfooli, A. A. Oskoobi, M. Semnani-Rahbar, Identifying and evaluating the environmental aspects and consequences of oil platforms using FMEA method (case study: Forouzan oil platforms), Tehran Publication, 2012

[15] S. A. Jozi, M. Irankhah, Environmental risk evaluation of oil pipelines using AHP method, Journal of Ecology, Tehran University, 2009

[16] S. E. Seyedneme, F. Karimi-Organi, Safety risk assessment and health of oil and gas companies, 1st Scientific Congress on Development of Agricultural Sciences, Tehran University, 2015

[17] S. Rezaeian, M. Irankhahi, S. A. Jozi, "Presenting and environmental risk assessment pattern for gas transmission projects using indexing and AHP methods", Environmental Science and Technology, Vol. 16, No. 62, pp. 11-23, 2014

[18] S. A. Jozi, N. Goloji, I. Mohammadfam, "Environmental risk assessment and evaluation in Aria-Rasoul Polymer Company, Polyethylene Unit, using EFMEA method", Natural Resources Science and Technology, Vol. 2, No. 4, pp. 147-159, 2011

[19] E. Audsley, M. Brander, J. C. Chatterton, D. Murphy-Bokern, C. Webster, A. G. Williams, How low can we go? An assessment of greenhouse gas emissions from the UK food system and the scope reduction by 2050, Report for the WWF and Food Climate Research Network, 2010

[20] A. C. Bejarano, J. Michel, "Large-scale risk assessment of polycyclic aromatic hydrocarbons in shoreline sediments from Saudi Arabia: Environmental legacy after twelve years of the Gulf war oil spill", Environmental Pollution, Vol. 158, No. 5, pp. 1561-1569, 2010

[21] M. J. Nieuwenhuijsen, Exposure assessment in environmental epidemiology, Oxford University Press, USA, 2015

[22] K. Glenn, M. Jansen, O. Gutierrez, "Quantitative Risk Assessment", OH3/Assessments, Cost Estimates \& Schedules Office (ACES), August 27 th, 2015

[23] K. E. Hammermeister, W. G. Henderson, M. R. Bronsert, E. JuarezColunga, R. A. Meguid, "Bringing quantitative risk assessment closer to the patient and surgeon: a novel approach to improve outcomes", Annals of Surgery, Vol. 263, No. 6, pp. 1039-1041, 2016.

[24] Y. Y. Haimes, Risk modeling, assessment, and management, John Wiley \& Sons, 2015

[25] G. E. Apostolakis, "How useful is quantitative risk assessment?", Risk Analysis, Vol. 24, No. 3, pp. 515-520, 2004

[26] M. Abtahi, B. Kaasa, J. E. Vindstad, T. Ostvold, "Calcium carbonate precipitation and ph variations in oil field waters: a comparison between experimental data and model calculations", Acta Chemica Scandinavica, Vol. 50, No. 2, pp. 114-121, 1996

[27] E. Zagerdi, H. Nayebi, N. Sydhsam al-Amin, A. Mehrfar, "Banned in terms of the rescheduling trains Passenger rail network lines", Journal of Transportation Engineering, Vol. 3, No. 3, pp. 10-25, 2014

[28] A. Samimi, On the assessment and management of environmental risks in Abadan, Abadan Publication, Iran, 2013

[29] A.Mortazavi, S. Zranzhad, M. Khans, O. Asilian Mahabad, "Examine the factors related to the occurrence of accidents in the construction phase of the oil, gas and petrochemical industries in Assaluyeh", Scientific Journal Martyr Yazd University of Medical Sciences, Vol. 15, No. 4, pp. 75-83, 2007 